\title{
Optimizing the Role of Tempe Makers in the Development of KAMPUNG TEMPE Potentials as the Pioneer of Food and Climate Sovereignty
}

Ambar Fidyasari', Wirastika Adhihapsari' ${ }^{2}$, Sentot Joko Raharjo ${ }^{1}$

${ }^{1}$ Academic of Pharmacy and Food Analysis of Putra Indonesia Malang Jl. Barito No 5 Malang65123

2IKIP PGRI Jember Jl. Jawa No 10 Jember-68121

Email: fidyafloss@gmail.com; sjraharjozoom@gmail.com; sentotjoko@yahoo.co.id

\section{Article History:}

Received: July $27^{\text {th }} 2020$

Revised: Feb $11^{\text {th }} 2021$

Accepted: May 30 th 2021

Keywords: kampung tempe, quick tempe, Glucono DeltaLactone
Abstract: Beji Village, Junrejo Sub-District of Batu City has been known as "Kampung Tempe" as most of the people produce tempe. Active participation from universities is definitely important to assist the production of "tempe" in Beji village. This assistance program is aimed to enhance the production of " tempe" to optimize the production yield, timeefficiency and hygiene which also generate adequate profits. The target subjects of this social assistance program was the group of SMSE "tempe" active businessmen in "Kampung Tempe". The program included assistance in producing "Tempe" using Glucono Delta-Lactone method. This technology was expected to be the solution to address problems related to inconsistent quality due to the use of traditional method without reducing the taste and quality. This program was administered as a training program which included advisory, demonstration and independent assistance. The results of this research showed that the program successfully improved subjects' knowledge on the use of more efficient method which produced "tempe" with better quality within shorter time, making the cash flow more efficient

\section{Introduction}

Beji Village is a center of tempe production, which residents mostly work as tempe businessmen, especially the residents of RT 03 RW 01. This village is then well known as "Kampung Tempe". The production of tempe by this MSME group reaches approximately 200 to $300 \mathrm{~kg} /$ day. Tempe is a traditional food in Indonesia, and Indonesia ranked 1st in tempe production. Indonesia is also the largest soybean market in Asia. Tempe has dominated the soybean consumption by $50 \%$, followed by tofu $(40 \%)$ and the rest $10 \%$ for other products (such as tauco, soy sauce and others). Tempe is an authentic 
Indonesian food made through soybean fermentation using Rhizopus spp fungus. Tempe is considered as 'low cost nutritious food' that is consumed by all socio-economic groups in Indonesia

Tempe production requires long time due to temperature-related issues. Excessive temperature causes tempe to rot, while temperature that is too cold brings failure in tempe production. The use of TC technology is expected to support the programs of the Ministry of Industry, the Ministry of Cooperatives and SMEs, and environmental management institutions especially related to the development of future needs. Wijaya et al, (2015) has submitted an innovation (patent) in 2007 for tempe production using a chemical acidification process, in which ingredients are boiled in a Glucono Delta-Lactone (GDL) solution. This innovation named one of 100 Indonesian Innovations called "Quick Tempe"

The long production process that takes up to 4 days has been a general issue among tempe makers. Technology that could make this process faster is obviously needed to improve this process. "Quick Tempe" (QT) technology was first introduced at the Bogor Agricultural Institute which is also included in 100 Indonesian Innovations in 2008 by the Ministry of Research and Technology and Business Innovation Center. This technology focuses on the acidification stage, in which gluconic acid obtained from glucono delta-lactone compounds or often abbreviated as GDL is used. ${ }^{1}$

The trial of Quick Tempe technology implementation showed positive results that are worth following up. Tempe produced using $Q T$ technology is not significantly different from the ones produced using traditional method, even the quality is better and preferred by consumers. There is a need for dissemination and assistance as technology transfer considering the diverse conditions in each region. QT technology is expected support the programs held by the Ministry of Industry, the Ministry of Cooperatives and SMEs, and environmental management institutions especially the ones related to the development of future needs.

Therefore, Beji Village, Junrejo District, Batu City is known as "Kampung Tempe" because most of the people produce tempe. Active participation from universities is a supporter to help tempe production in Beji village. This mentoring program aims to increase the production of "tempe" to optimize production results, time efficiency and cleanliness which also produces adequate profits through fast tempe production.

\section{Methods}

The strategy of community service activities in "Kampung Tempe" in Beji Village, Junrejo District, Batu City is by changing environmental conditions as expected by providing assistance for fast tempe production to optimize production results, time

\footnotetext{
${ }^{1}$ Wijaya, C.H, Siti Nurjanah dan Qabul Dinanta Utama. Implementasi dan Analisis Keuntungan Teknologi Back-Slopping pada Pembuatan “Quick Tempe” Skala Industri Rumah Tangga. Jurnal Pangan, Vol. 24 No. 1 (2015): 49-62
} 
efficiency, cleanliness and profits through the ABCD (Asset Based Community) approach. Development). In this $\mathrm{ABCD}$ approach, the service team provides assistance so that the community has social transformation capabilities based on their abilities. ${ }^{2}$

The service team positioned itself by bridging the community to recognize the potential in order to develop knowledge and make changes by having the ability to process the fast tempeh production they produce in order to optimize production results, time efficiency, cleanliness and profits and later have an impact on those around them.

There are several stages carried out by the team in carrying out this assistance, including the stages of socialization, discovery, design, define, and reflection. In the Inculturation stage, it was carried out to get to know the Tempe Crafts Community closer through socialization, then Mapping the Assets and Potentials of several tempe craftsmen through the Discovery stage. After knowing the potential, the Design - Define - Reflection stage was carried out by the team to identify various opportunities from potential and assets, as well as determining and implementing work programs for "Kampung Tempe" Craftsmen in Beji Village, Junrejo District, Batu City.

\section{Result}

The inculturation and discovery stages were carried out by the team through a community map and transectal. The team visited and observed the Tempe Craftsmen Community in the Beji Village area, Junrejo District, Batu City. The team also communicated with tempe craftsmen through outreach activities. In the socialization of this new method to the tempe craftsmen, it is certainly not easy, because it is difficult to change habits. This session was held twice at the village hall, as shown in Figure 1. Next, an online workshop focused on nutrition in tempe was conducted with Professor of Tempe, Mr. Made Astawan, a professor at the Bogor Agricultural Institute. Thus, the service team will get to know more about the tempe craftsmen who will be the assisted partners of this service activity. The results of this stage indicate that the Tempe Business Community already has a strong market segment and selling power. The results of tempe products are widely known to the public, so that tempe production is very high to be able to supply the needs of tempe in the Batu area and its surroundings.

${ }^{2}$ Wiwik Handayani, Sri Suryani Yuprapti Winasih, Sinta Dewi, dan Badi'ah. Pendampingan Pembuatan Pakan Ternak dari Limbah Pembungkus Lontong untuk Peningkatan Ekonomi Masyarakat di Kelurahan Kupang Krajan Kecamatan Sawahan Kota Surabaya. Jurnal Pengabdian Masyarakat ENGAGEMENT. Vol. 04, No 02 (2020): $551-562$ 


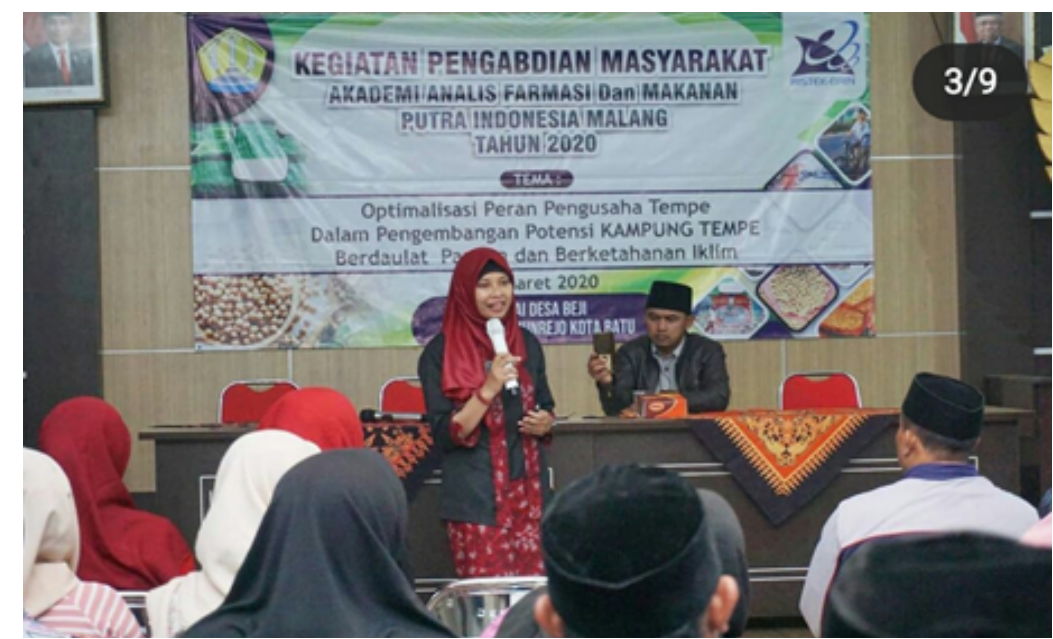

Figure 1. The Socialization Activity of Making Quick Tempe in Beji Village Hall, Kota Batu

This is reflected in the official website of the Batu City government which places Tempe Village as an icon in addition to other villages with environmental themes in Batu. This is proof that Tempe Beji Batu Village has received good attention so that it becomes one of pride for the Batu City Government. Given this reality, the companion team carried out the design and define stages through the following activities: (1) Institutional \& Organizational Mapping, namely identifying the organizational capacity of tempe craftsmen to photograph the "energy" of tempe crafters; (2) Individual Inventory Skill, namely conducting individual assets using interviews and focus group discussions (FGD) with lontong craftsmen; (3) Leaky Bucket; by recognizing, identifying and analyzing production activities and the economic turnover of tempe crafters; and (4) Low Hanging Fruit which is used in determining the desires and expectations of tempe craftsmen based on their own potential and assets without any outside assistance. As a result of the design and define stages, the team conducted a FGD with tempe craftsmen and residents of Beji Village, Junrejo District. They realized that the quick results of tempe products would be very helpful and improve their family's economy.

The companion team conducted training and assistance in the production of fast tempeh with residents of RW 01 RT 03 Beji Village, Junrejo District which was carried out in August 2020. Several tempe craftsmen were willing to be helped to make quick tempe using the Glucono Delta-Lactone (GDL) method. In the tempeh production process, acidification is an important step, because acidification can be done naturally or using chemical substances. The natural acidification process is widely preferred by tempe makers by soaking boiled soybeans at a temperature of $28-31^{\circ} \mathrm{C}$ until the water becomes foamy and smells acidic. ${ }^{3}$ Chemical acidification is usually done in subtropical climates, where the natural acidification could not run well. ${ }^{4}$ Chemical acidification employs

\footnotetext{
${ }^{3}$ Liu K.. Soybean Chemistry, Technology, and Utilization. New York: Chapman \& Hall,
} International Thomson Publ. (1997).

${ }^{4}$ Nout MJR dan Kiers JL.. A Review Tempe Fermentation, Innovation, and Functionality: Update 
chemical substances to form suitable conditions for mold growth. Natural acidification can be replaced by chemical acidification. ${ }^{5}$

Glucano Delta Lactone (GDL) is an acidic substance used in tempe production without affecting the flavor of tempe. GDL is a food additive that is Generally Recognized as Safe (GRAS). ${ }^{6}$ GDL is commercially available and it has been widely used in food industry (6). This substance is commonly used as a lump in tempe production. ${ }^{7}$ These followings are steps in tempe production using GDL, as shown Figure 2.

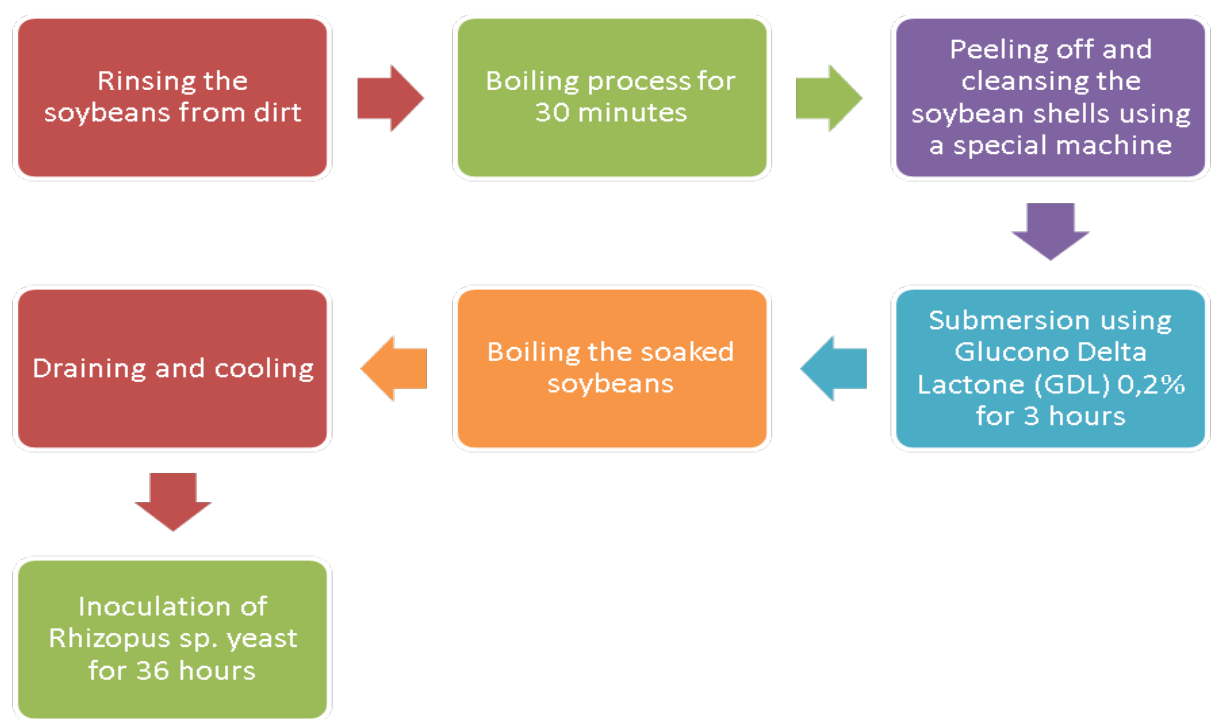

Figure 2. The step of tempe production using Glucano Delta Lactone

Those steps make tempe production faster compared to using conventional method. Tempe production using this GDL method takes only 2 days, making the cash flow more efficient. The difference between GDL method and conventional method is in the acidification process. The acidification process in conventional method takes approximately one night, while it only takes 3 hours in GDL method, making the production using GDL method more efficient. The independent assistance conducted to tempe makers in Beji Village, as shown Figure 3 [A].

Tempe produced using GDL method is better in terms of organoleptic visibility as it has brighter color since the mold is more evenly distributed due to stable acidification process. The acidification process of boiled soybeans inhibits the growth of pathogenic bacteria and provide suitable environmental conditions for mold growth. ${ }^{8}$ Chemical

into The Third Millenium. Journal of Applied Microbiology. 8(4) (2005):789-805.

${ }^{5}$ Warisno dan Kres D. Meraup Untung dari Olahan Kedelai. Jakarta: PT. Agromedia Pustaka.(2010).

${ }^{6}$ [FDA] Food Drugs Administration. Code Of Federal Regulation Tittle 21. Maryland (US) : U.S Food and Drugs Administration. (2013).

${ }^{7}$ GuoQing, JIA, Shi QIU, GuanNa LI, Jun ZHOU, Zhaochi FENG, Can LI.. Alkali-Hidrolysis of D-

Glucono-Delta-Lactone Studied by Chiral Raman and Circulation Dichroism Spectroscopies. Science China Series B-Chemistry. 52(5) (2009): 552-558.

${ }^{8}$ Sarwono, B. dan Saragih, YP. Membuat Aneka Tahu. Penebar Swadaya Jakarta (2004). 
acidification can shorten the soaking time to 2-3 hours compared to natural acidification which takes 20-30 hours. ${ }^{9}$ The taste of tempe produced using GDL method is not significantly different from the one made using natural acidification. The texture of tempe produced using GDL method is more compact and dense, while the natural acidification process produces rather unstable texture. The $\mathrm{pH}$ level of soybeans soaked in acid solution generally ranges between of $4.3-5.7 .{ }^{10}$ If the initial $\mathrm{pH}$ of the boiled soybeans is not low enough, pathogens will grow and damage the tempe product. Bacteria cannot grow in soybeans with pH level of 5 or lower. In addition, mold growth will be slightly slower when the $\mathrm{pH}$ level is lesser than 3.5.11 Those factors have effects on the texture of tempe. Therefore, the use of GDL brings 3 benefits: faster production time without reducing the nutritional and organoleptic properties of tempe, improved knowledge of tempe makers, and more efficient cash flows. Tempe products produced using GDL method and natural acidification method, as shown Figure 3 [B].
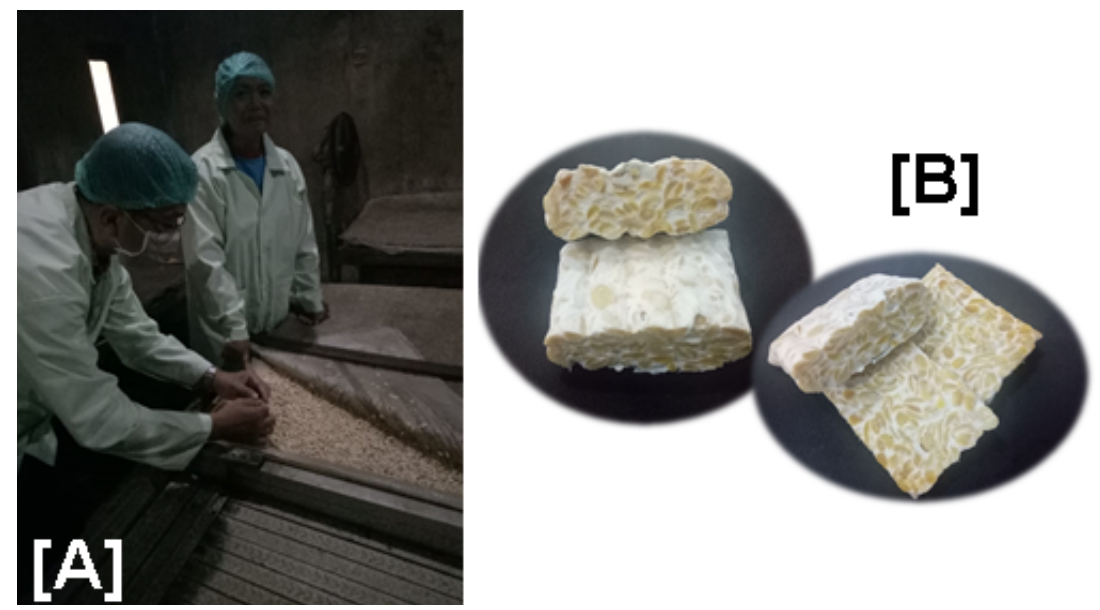

Figure 3. [A] The independent assistance conducted to tempe makers in Beji Village using Glucano Delta Lactone Methods [B]Tempe Product using Glucano Delta Lactone Methods

The last stage in this mentoring is a reflection which shows the results that the tempe craftsmen in the RT. 03 RW. 01 Beji Village, Junrejo District, Batu City, has had the opportunity to manage the production of fast tempeh making which of course will optimize its production, efficient production time, environmental cleanliness and profits and will have an impact on those around them.

\section{Discussion}

Indonesia is the top tempe producer in Asia and even in the world. Tempe is a

\footnotetext{
${ }^{9}$ Wijaya, C.H, Siti Nurjanah dan Qabul Dinanta Utama. Implementasi dan Analisis Keuntungan Teknologi Back-Slopping pada Pembuatan “Quick Tempe” Skala Industri Rumah Tangga

${ }^{10}$ Liu K.. Soybean Chemistry, Technology, and Utilization.

${ }^{11}$ Kuswanto, KR. Industrialization of tempe fermentation. dalam Steinkraus KH Industrialization of Indigenous Fermented Foods. ${ }^{2 n d}$ ed. New York: Marcel Dekker (2004).
} 
Super Food that is being registered to UNESCO as an intangible cultural heritage of the nation or 'Intangible Cultural Heritage of Humanity. In regards to the considerable potential of tempe, it is necessary to develop a method in the tempe production to make it faster and more efficient. Thus, this assistance program was conducted.

This community service assistance was conducted in Beji Village to disseminate information about how to make tempe quickly. In this village, tempe makers used different methods in making tempe based on the ancestral heritage in the process of making tempe. There are three ways used in tempe production: tempe siraman, tempe tindihan and tempe plastic, each of which has different characteristics and different production processes. Meanwhile, the time required for the production was similar between 3 to 4 days. To speed up this process, Glucono Delta-Lactone (GDL) can be employed to acidify the tempe.

The assistance program has successfully revealed the common causes affecting unstable tempe products, as shown Figure 1-4. Follow up assistance was also provided to solve the problem by minimizing the ratio of the failed products. The food production has been improved by implementing GMP (Good Manufacturing Practices). This procedure consists of prerequisites and guidelines in food production in standardized sanitary conditions. GMP guarantees the hygiene of the entire stages of the food production process from the ingredient supply to the final products. GMP is also designed to control the risk of food contamination by unintended materials, microbes, hazardous chemicals, and other contaminants during the production process. ${ }^{12}$

The team performed the simulation by practicing the correct process of tempe production where high quality tools were used to produce high quality tempe. After that, groups of tempe makers practiced the procedures to be observed. Required equipment were fulfilled including shoes, , hair cover gloves, masks to guarantee the personal hygiene. Simulation of how to carry out equipment maintenance, media cleaning facilities, sanitary equipment, work space in accordance with GMP was conducted. Further, simulations on waste disposal and handling facilities, lighting facilities, antiinsect floor cleaning and gutters were also carried out. All of those simulations were performed and assisted in such way to make sure that all trainees have adequate understanding that GMP is a proper way to produce safe, healthy and nutritious products. The following the assistance program was directed to enhance the sovereign food and climate resilience products, as shown Figure 4. The evaluation of this assistance program was done using two approaches, namely internal and external approaches. External approach was performed by distribution closed-ended questionnaire to all trainees, while internal approach was conducted by observing and analyzing shortcomings and unfulfilled needs during the activity. Evaluation was performed to provide the best

\footnotetext{
${ }^{12}$ Babu, PD, Bhakyaraj, R ,Vidhyalakshmi, R. A Low Cost NutritiousFood “Tempe” - A Review. World Journal of Dairy \& Food Sciences 4(1) (2009):22-27; ISO 15161:2001, Guidelines on the application of ISO 9001:2000 for the food and drink industry (2001).
} 
service. Based on the training evaluation chart, it can be concluded that $92.50 \%$ of respondents found the community service program beneficial, $71.43 \%$ of respondents agreed that quick tempe production training activities was very helpful in enhancing the cash flow efficiency, $90.24 \%$ of respondents agreed that their knowledge has improved after attending the training, and $85.43 \%$ of them found the overall training activities good. To note, based on the results of the questionnaires, the education background of tempe makers varied. Whilst, education background is very influential on the intention to innovate and make breakthroughs for the advancement of human resources. This issue should be approached in gradual manner in order to make the material delivery effective regarding respondents' characteristics.

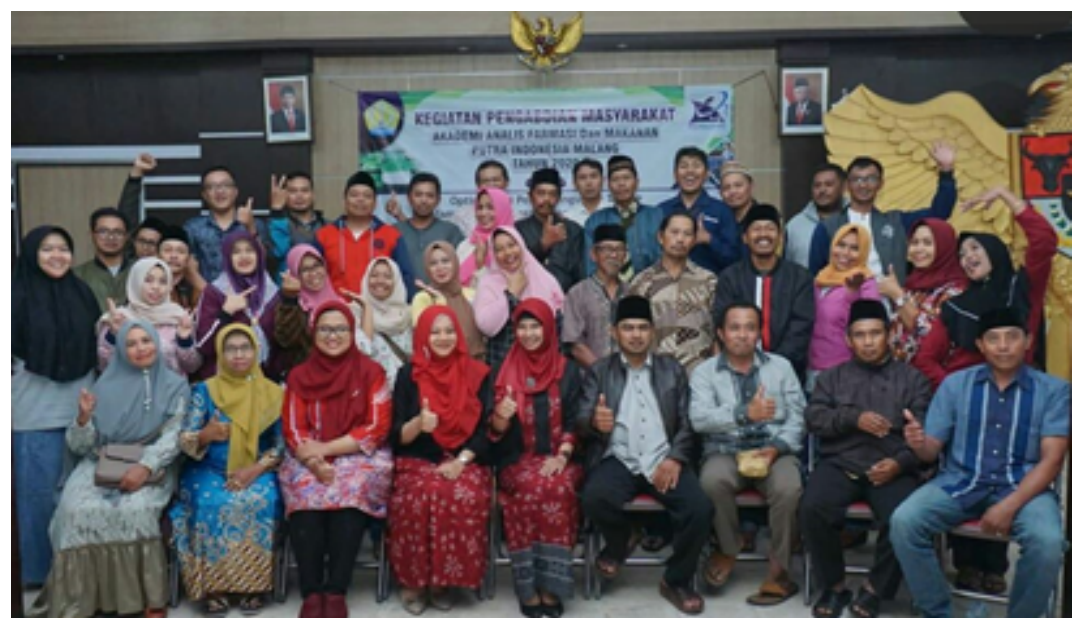

Figure 4. The assistance program was directed to enhance the sovereign food and climate resilience products

\section{Conclusion}

The implementation of the community service program showed that Glucono Delta Lactone (GDL) can be applied tempe production to produce tempe with better organoleptic properties in shorter time and to make the cash flow more effective. The implementation of Good Manufacturing Practices (GMP) has made Kampung Tempe, the pioneer of food and climate sovereignty. Synergetic action should be enhanced to provide assistance regarding the implementation of Glucono Delta Lactone method among colleges, village government, as well as the department of industries and trades of Batu City. 


\section{Acknowledgements}

The authors acknowledge the Ministry of Research and Technology of the Republic of Indonesia for granting the Community Service Scheme in the Community Partnership Program in 2020. Thank you also to the lecturers and students of the Academic of Pharmacy and Food Analysis of "Putra Indonesia Malang" and the people of Beji Village, Kota Batu

\section{References}

Babu, PD, Bhakyaraj, R ,Vidhyalakshmi, RA Low Cost NutritiousFood "Tempe" - A Review. World Journal of Dairy \& Food Sciences 4(1) (2009): 22-27.

[FDA] Food Drugs Administration. Code Of Federal Regulation Tittle 21. Maryland (US): U.S Food and Drugs Administration (2013).

GuoQing, JIA, Shi QIU, GuanNa LI, Jun ZHOU, Zhaochi FENG, Can LI. Alkali-Hidrolysis of D-GluconoDelta-Lactone Studied by Chiral Raman and Circulation Dichroism Spectroscopies. Science China Series B-Chemistry. 52(5) (2013): 552-558.

ISO 15161. Guidelines on the application of ISO 9001:2000 for the food and drink industry (2001)

Kuswanto, KR. Industrialization of tempe fermentation. dalam Steinkraus KH Industrialization of Indigenous Fermented Foods. 2nded. New York: Marcel Dekker (2004).

Liu K.. Soybean Chemistry, Technology, and Utilization. New York: Chapman \& Hall, International Thomson Publ. (1997).

Nout MJR dan Kiers JL. A Review Tempe Fermentation, Innovation, and Functionality: Update into The Third Millenium. Journal of Applied Microbiology 98(4) (2005): 789-805.

Sarwono, B. dan Saragih, YP Membuat Aneka Tahu Cetakan III. Jakarta: Penebar Swadaya (2004)

Warisno dan Kres D. Meraup Untung dari Olahan Kedelai. Jakarta: PT. Agromedia Pustaka (2010). Wijaya, C.H, Siti Nurjanah dan Qabul Dinanta Utama. Implementasi dan Analisis Keuntungan Teknologi Back-Slopping pada Pembuatan "Quick Tempe" Skala Industri Rumah Tangga. Jurnal Pangan, Vol. 24 No. 1 (2015): 49-62.

Wiwik Handayani, Sri Suryani Yuprapti Winasih, Sinta Dewi, dan Badi'ah. Pendampingan Pembuatan Pakan Ternak dari Limbah Pembungkus Lontong untuk Peningkatan Ekonomi Masyarakat di Kelurahan Kupang Krajan Kecamatan Sawahan Kota Surabaya. Jurnal Pengabdian Masyarakat ENGAGEMENT. Vol. 04, No 02 (2020): 551 - 562 